\title{
Polymorphonuclear cell motility, ankylosing spondylitis, and HLA B27
}

\author{
COLIN T. PEASE, JOHN N. FORDHAM, AND H. L. F. CURREY \\ From The Bone and Joint Research Unit, the London Hospital Medical College, and the Department of \\ Rheumatology, the London Hospital
}

\begin{abstract}
SUMMARY Polymorphonuclear leucocyte (PMN) function was studied in 29 subjects with ankylosing spondylitis (AS). Of these, 20 were HLA B27+ve and 9 B27-ve. There were 30 controls and, of these, 15 were B27+ve. Random and directed cell migration was measured by 2 techniques: migration through a micropore filter and migration under an agar film. The chemo-attractant was either casein-activated serum or zymosan-activated serum. By both techniques directed motility was increased in subjects with B27 or with AS when compared to the B27-ve controls. This suggests that the disease AS and the possession of B27 are both associated with increased PMN motility.
\end{abstract}

In recent years several studies have suggested that patients suffering from HLA B27-related diseases such as ankylosing spondylitis or yersinia arthritis show altered cellular or immunological functions. These reports, although sometimes contradictory, are of particular interest in that they point to these altered functions being associated, not with the disease per se, but with possession of HLA B27. In other words similar alterations in function are found in those with B27 who do not have clinical disease.

Evidence of this type has been reported in relation to suppression of the mixed lymphocyte reaction ${ }^{1}$ (the same group subsequently failed to repeat this observation $^{2}$ ), to suppression of responsiveness to phytohaemagglutinin stimulation, ${ }^{3}$ to increased antibody responses to streptokinase/streptodornase challenge, ${ }^{3}$ to increased polymorphonuclear (PMN) chemotaxis, ${ }^{4}$ and to the ability of serum to stimulate chemokinesis (undirected PMN motility). ${ }^{5}$ A brief preliminary report ${ }^{6}$ suggests somewhat similar findings in relation to PMN adherence and phagocytosis.

Significant differences in cellular and immunological functions between people with and those without B27 might have a bearing on the association between this tissue antigen and diseases such as ankylosing spondylitis. Of particular relevance is the question whether similar functional changes are present in patients with clinical disease who do not possess B27. One of these reports suggested that this was the case. ${ }^{1}$

Accepted for publication 23 February 1983

Correspondence to Dr C. T. Pease, Department of Rheumatology, Queen Mary's Hospital, Roehampton, London SW15 5PN.
We have tried to take this question further by comparing PMN motility, both directed and random, in 4 groups: ankylosing spondylitis patients with and without B27, and normal controls with and without B27. In addition the latter 2 groups have been compared with regard to PMN phagocytosis and adherence.

\section{Subjects and methods}

Blood samples were obtained from 29 patients with ankylosing spondylitis (AS). Of these, 20 were B27 + ve, 9 B27-ve. All fulfilled the criteria of Bennett and Wood, ${ }^{7}$ and all were attending as outpatients. None had experienced recent infections. Regular drug therapy (including piroxicam, naproxen, indomethacin, ibuprofen, diclofenac, and phenylbutazone) was not stopped for the experiment. Clinical disease activity was graded into:

Active. Significant trunk pain or active peripheral arthritis, morning stiffness in excess of one hour or acute anterior uveitis. Regular drug therapy required.

Probably active. Patients in whom an acute episode had settled incompletely, or in whom significant morning stiffness worsened if medication was forgotten.

Inactive. Symptomless or only mild back pain with less than 20 minutes morning stiffness. Medication, if any, often taken irregularly.

Blood samples were obtained also from 30 healthy control subjects. Half of them were B27 + ve, half 
- ve. On the basis of HLA B27 typing they were divided into age and sex matched pairs and tested in parallel. None had clinical evidence of inflammatory arthritis. In 24 in whom it was measured the mean ESR was $6(2-25) \mathrm{mm} / \mathrm{h}$. Among the female controls 4 were taking a contraceptive pill, one Premarin (a mixture of oestrogens), and one oxprenanolol. Table 1 compares various features in the patients and the controls.

\section{CELL PREPARATION AND MOTILITY STUDIES} These methods have been described in detail previously. ${ }^{8}$ Polymorphonuclear leucocytes were separated from heparinised blood by a HypaqueFicoll separation procedure. ${ }^{9}$ Cells were washed 3 times with medium 199 (Wellcome) supplemented with $1 \%$ albumin and then concentrated to $12 \times$ $10^{6} / \mathrm{ml}$ for use in the Boyden method and $41 \times 10^{6} / \mathrm{ml}$ for the agarose plate method. After the final wash approximately $98 \%$ cells were viable when tested by toluidine blue exclusion.

Boyden method. A total of $2.4 \times 10^{6} \mathrm{PMN}$ were spun by cytocentrifuge on to a $3 \mu \mathrm{m}$ Schleicher and Schüll cellulose acetate filter. Filters were placed in

Table 1 Details of patients with ankylosing spondylitis and the controls

\begin{tabular}{lllll}
\hline & \multicolumn{2}{l}{$\begin{array}{l}\text { Ankylosing } \\
\text { spondylitis }\end{array}$} & Controls \\
\cline { 2 - 5 } & B27+ve & B27-ve & B27+ve & B27-ve \\
\hline Sex & & & & \\
$\quad$ Male & 16 & 7 & 8 & 8 \\
$\quad$ Female & 4 & 2 & 7 & 7 \\
Age at onset & 21 & 20 & & \\
Current Age & $(10-56)$ & $(18-41)$ & & 31 \\
Disease activity & 41 & 39 & 34 & \\
$\quad$ Active & 3 & 1 & & \\
$\quad \begin{array}{l}\text { Probably active } \\
\text { Inactive }\end{array}$ & 1 & 1 & & \\
Drug consumption (NSAID) & 7 & & \\
$\quad$ Regular & 8 & 4 & & \\
Irregular & 6 & 5 & Nil & Nil \\
$\quad$ None & 6 & 5 & & \\
\hline
\end{tabular}

Sykes-Moore chambers and incubated at $37^{\circ} \mathrm{C}$ for 20 minutes. Random migration was measured with Hanks's balance salt solution (BSS) above and below the filter. Directed migration was measured with Hanks's solution containing $33 \%$ pooled serum with $0.5 \%$ casein as an activator in the lower chamber. The leading 2-cell front was measured in 5 fields on each filter with an electronic focusing micrometer, and each experiment was performed in duplicate.

Agarose plate method. Pairs of wells were cut in a 3 mm agar film, $2 \cdot 5 \mathrm{~mm}$ apart and $2.5 \times 10^{5} \mathrm{PMN}$ were placed in one well for studies of random migration. For directed migration zymosan-activated pooled serum was placed in the opposite well. The plates were incubated in a humidified incubator for $2 \frac{1}{2}$ hours at $37^{\circ} \mathrm{C}$ with $5 \% \mathrm{CO}_{2}$. The leading 2-cell front was measured and a cell migratory profile was constructed by counting the number of cells, which had reached set distances from the starting well, within a $100 \mu \mathrm{m}$ wide corridor separating the 2 wells (Fig. 1 ).

Leucotactic index. This was calculated by the method described by Maderazo and Woronick..$^{10}$ The average distance migrated per cell was the sum of the total distance each cell moved divided by the total number of cells within the specified area. An average of 4 cell rockets were counted per person.

Polymorph adherence. Polymorph adherence followed the method described previously by Fordham et al. ${ }^{8} 0 \cdot 3 \mathrm{ml}$ of heparinised blood was incubated for 10 minutes with scrubbed nylon fibre in a 1 $\mathrm{ml}$ disposable syringe, following which the effluent blood was collected and total and differential white cell counts performed on the pre- and postincubation specimens. Adherence was expressed as the percentage of PMN retained in the column. Samples were tested in triplicate and a mean value calculated.

Phagocytosis. Phagocytosis followed the method described previously by Fordham et al. ${ }^{8}$ Candida blastospores were opsonised with pooled AB serum and then incubated with PMNs at a ratio of 10:1 for 30 minutes. Phagocytosis was assessed as the mean number of phagocytosed or attached candida blastospores per PMN (the phagocytic index). Samples were tested in duplicate and a mean calculated.

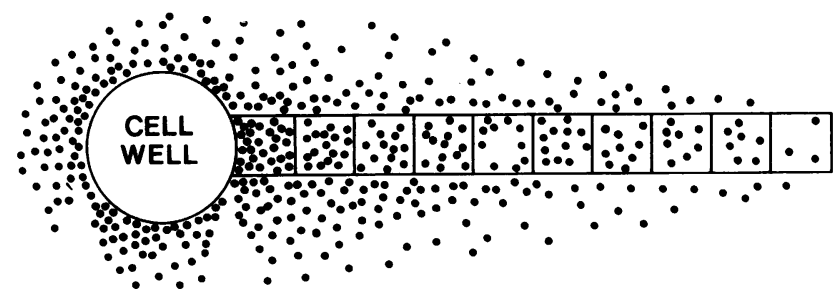

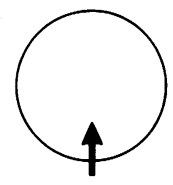

Zymosan activated serum
Fig. 1 Diagram (not to scale) of $P M N$ cell migration from the cell well towards the chemoattractant (Zymosan-activated serum). A $100 \mu \mathrm{m}$ grid is superimposed to allow counting of cell numbers within each specified area. 
Statistics. Statistical analysis of the differences between the pairs was tested by the Wilcoxon rank sum test for paired data. Other results were analysed by 2-way analysis of variance (Anova).

\section{Results}

PMN motility. Among the AS patients, there was no evidence that either disease duration or disease activity influenced any aspect of cell motility.

(1) Filter technique. Table 2 compares the leading 2-cell front for random and directed motility in 19 B27 + ve and 9 B27 - ve patients compared with 15 B27 + ve and B27 - ve control pairs. Directed motility in control subjects with B27 and in patients with AS was significantly greater than in the B27 -ve control group. There was no significant difference between the B27 + ve controls and patients with AS.
Comparison of the 2 control groups by Wilcoxon paired analysis (data not illustrated) was significant at $p=0.003$. Random motility was slightly greater in the B27 - ve control group than in the B27 + ve control group and the AS patients, but these differences did not reach statistical significance (Wilcoxon).

(2) Agarose plate technique. Table 3 compares results for the leading 2-cell front for random and directed motility in 18 B27 + ve AS, 7 B27 - ve AS and $15 \mathrm{~B} 27$ + ve and - ve control pairs. Directed motility in controls with B27 and in AS patients was significantly greater than in the B27 - ve controls. Subjects without B27 but with AS gave the greatest values. Comparison of the 2 control groups by Wilcoxon did not reach significance $(p=0 \cdot 069)$. Random motility was greatest in the B27 - ve control group and was significantly greater than in the B27 +ve

Table 2 Directed and random motility results obtained by the Boyden filter method

\begin{tabular}{|c|c|c|c|c|}
\hline & $\begin{array}{l}\text { B27-ve } \\
\text { Control } \\
(n=15)\end{array}$ & $\begin{array}{l}\text { B27+ve } \\
\text { Control } \\
(n=15)\end{array}$ & $\begin{array}{l}B 27-v e \\
A S \\
(n=9)\end{array}$ & $\begin{array}{l}B 27+v e \\
A S \\
(n=19)\end{array}$ \\
\hline Directed motility $\mu \mathrm{m}$ & $\begin{array}{l}87 \\
\text { (SEM 4.3) }\end{array}$ & $\begin{array}{l}99 \cdot 8 \\
\text { (SEM 5.62) }\end{array}$ & $\begin{array}{l}104 \cdot 0 \\
\text { (SEM 8.9) }\end{array}$ & $\begin{array}{l}98 \cdot 6 \\
\text { (SEM 5.21) }\end{array}$ \\
\hline Random motility $\mu \mathrm{m}$ & $\begin{array}{l}57 \cdot 5 \\
\text { (SEM 2.13) }\end{array}$ & $\begin{array}{l}54 \cdot 2 \\
\text { (SEM 2.80) }\end{array}$ & $\begin{array}{l}54 \cdot 5 \\
\text { (SEM 2.42) }\end{array}$ & $\begin{array}{l}54 \cdot 6 \\
\text { (SEM 2.12) }\end{array}$ \\
\hline \multicolumn{5}{|c|}{ Statistical analysis (Anova) } \\
\hline $\begin{array}{l}\text { Directed motility } \\
\text { B27 - ve control } \\
\text { B27 + ve control }\end{array}$ & & 0.001 & $\begin{array}{l}0.001 \\
\text { NS }\end{array}$ & $\begin{array}{l}0.001 \\
\text { NS }\end{array}$ \\
\hline $\begin{array}{l}\text { Random motility } \\
\text { B27 - ve control } \\
\text { B27 + ve control }\end{array}$ & & 0.036 & $\begin{array}{l}\text { NS } \\
\text { NS }\end{array}$ & $\begin{array}{l}0.047 \\
\text { NS }\end{array}$ \\
\hline
\end{tabular}

SEM = standard error of mean. NS = not significant.

Table 3 Directed and random motility results by the agarose plate method

\begin{tabular}{|c|c|c|c|c|}
\hline & $\begin{array}{l}\text { B27-ve } \\
\text { Control } \\
(n=15)\end{array}$ & $\begin{array}{l}\text { B27+ve } \\
\text { Control } \\
(n=15)\end{array}$ & $\begin{array}{l}B 27-v e \\
A S \\
(n=7)\end{array}$ & $\begin{array}{l}B 27+v e \\
A S \\
(n=18)\end{array}$ \\
\hline Directed motility $\mu \mathrm{m}$ & $\begin{array}{l}1470 \\
(\mathrm{SEM} \mathrm{42 \cdot 7)}\end{array}$ & $\begin{array}{l}1592 \\
\text { (SEM 52.4) }\end{array}$ & $\begin{array}{l}1902 \\
\text { (SEM 68.3) }\end{array}$ & $\begin{array}{l}1551 \\
\text { (SEM 47·2) }\end{array}$ \\
\hline Random motility $\mu \mathrm{m}$ & $\begin{array}{l}783 \\
\text { (SEM 44.5) }\end{array}$ & $\begin{array}{l}746 \\
\text { (SEM 44.8) }\end{array}$ & $\begin{array}{l}803 \\
\text { (SEM 59.9) }\end{array}$ & $\begin{array}{l}676 \\
\text { (SEM 38.8) }\end{array}$ \\
\hline \multicolumn{5}{|c|}{ Statistical analysis (Anova) } \\
\hline $\begin{array}{l}\text { Directed motility } \\
\text { B27 - ve control } \\
\text { B27 + ve control }\end{array}$ & & $0 \cdot 001$ & $\begin{array}{l}0.001 \\
0.001\end{array}$ & $\begin{array}{l}0.04 \\
\text { NS }\end{array}$ \\
\hline $\begin{array}{l}\text { Random motility } \\
\text { B27 - ve control } \\
\text { B27 + ve control }\end{array}$ & & 0.03 & $\begin{array}{l}\text { NS } \\
\text { NS }\end{array}$ & $\begin{array}{l}0.001 \\
\text { NS }\end{array}$ \\
\hline
\end{tabular}


patients (Anova). Again, the difference between the B27 + ve and - ve control groups did not reach significance (Wilcoxon).

Total cell numbers. The total numbers of cells migrating within a $100 \mu \mathrm{m}$ corridor (Fig. 1) are shown in Table 4. Significantly, more cells migrated towards the chemoattractant in patients with AS and B27 + ve controls than in the B27 - ve controls.

Leucotactic index. This was calculated for 18 B27 +ve AS, 7 B27 - ve AS and 15 B27 + ve and B27 - ve control pairs. Table 5 shows the results. B27 + ve controls and patients with AS had a greater leucotactic index, with directed motility, than did the B27 - ve control group. Without a chemoattractant the index was significantly reduced among the AS patients with B27.
PMN migratory profile. Fig. 2 shows the final distribution of cells at the end of $2 \frac{1}{2}$ hours' incubation. It highlights the differences between the 4 groups for directed mobility and the similarities between them for random motility.

$P M N$ adherence. Eight pairs of control subjects were tested. The mean percentage of cells adherent to the nylon fibres was $59.8 \%$ (SD 5.6\%) in the B27 +ve and $64 \cdot 1 \%$ (SD $6 \cdot 8 \%$ ) in the B27 - ve group. This difference does not reach statistical significance.

$P M N$ phagocytes. Eight pairs of control subjects were tested. The mean numbers of candida blastospores adherent or phagocytosed were identical: $6 \cdot 6$ (SD 0.6) in the B27 group and 6.6 (SD 0.8) in the B27 - ve group.

Table 4 Total number of polymorphonuclear cells migrating within a 100 um corridor of agarose plates (see Fig. 1)

\begin{tabular}{|c|c|c|c|c|}
\hline & $\begin{array}{l}\text { B27-ve } \\
\text { Control } \\
(n=15)\end{array}$ & $\begin{array}{l}\text { B27+ve } \\
\text { Control } \\
(n=15)\end{array}$ & $\begin{array}{l}B 27-v e \\
A S \\
(n=7)\end{array}$ & $\begin{array}{l}B 27+v e \\
A S \\
(n=18)\end{array}$ \\
\hline Directed motility $\mu \mathrm{m}$ & $\begin{array}{l}196 \\
\text { (SEM 17.5) }\end{array}$ & $\begin{array}{l}265 \\
\text { (SEM 29.7) }\end{array}$ & $\begin{array}{l}343 \\
(\text { SEM 46.9) }\end{array}$ & $\begin{array}{l}306 \\
\text { (SEM 19.3) }\end{array}$ \\
\hline Random motility $\mu \mathrm{m}$ & $\begin{array}{l}85 \\
\text { (SEM 12) }\end{array}$ & $\begin{array}{l}83 \\
(\mathrm{SEM} \mathrm{10} \\
\text { (0.5) }\end{array}$ & $\begin{array}{l}99 \\
(\mathrm{SEM} 24 \cdot 2)\end{array}$ & $\begin{array}{l}69 \\
(\mathrm{SEM} 6 \cdot 35)\end{array}$ \\
\hline \multicolumn{5}{|c|}{ Statistical analysis (Anova) } \\
\hline $\begin{array}{l}\text { Directed motility } \\
\text { B27 - ve control } \\
\text { B27 + ve control }\end{array}$ & & 0.002 & $\begin{array}{l}0.001 \\
0.01\end{array}$ & $\begin{array}{l}0 \cdot 001 \\
\text { NS }\end{array}$ \\
\hline $\begin{array}{l}\text { Random motility } \\
\text { B27 - ve control } \\
\text { B27 + ve control }\end{array}$ & & NS & $\begin{array}{l}\text { NS } \\
\text { NS }\end{array}$ & $\begin{array}{l}\text { NS } \\
\text { NS }\end{array}$ \\
\hline
\end{tabular}

Table 5 Leucotactic index calculated from directed and random cell rockets using the agarose plate

\begin{tabular}{|c|c|c|c|c|}
\hline & $\begin{array}{l}\text { B27-ve } \\
\text { Control } \\
(n=15)\end{array}$ & $\begin{array}{l}\text { B27+ve } \\
\text { Control } \\
(n=15)\end{array}$ & $\begin{array}{l}B 27-v e \\
A S \\
(n=7)\end{array}$ & $\begin{array}{l}B 27+v e \\
A S \\
(n=18)\end{array}$ \\
\hline Directed motility $\mu \mathrm{m}$ & $\begin{array}{l}462 \\
(\mathrm{SEM} 21 \cdot 2)\end{array}$ & $\begin{array}{l}511 \\
\text { (SEM 36.6) }\end{array}$ & $\begin{array}{l}596 \\
\text { (SEM 29·3) }\end{array}$ & $\begin{array}{l}530 \\
\text { (SEM 25) }\end{array}$ \\
\hline Random motility $\mu \mathrm{m}$ & $\begin{array}{l}242 \\
\text { (SEM 18.6) }\end{array}$ & $\begin{array}{l}240 \\
(\text { SEM 8. 8) }\end{array}$ & $\begin{array}{l}241 \\
\text { (SEM 23.9) }\end{array}$ & $\begin{array}{l}197 \\
\text { (SEM 10.6) }\end{array}$ \\
\hline \multicolumn{5}{|c|}{ Statistical analysis (Anova) } \\
\hline $\begin{array}{l}\text { Directed motility } \\
\text { B27 - ve control } \\
\text { B27 + ve control }\end{array}$ & & $0 \cdot 002$ & $\begin{array}{l}0 \cdot 001 \\
\text { NS }\end{array}$ & $\begin{array}{l}0 \cdot 001 \\
\text { NS }\end{array}$ \\
\hline $\begin{array}{l}\text { Random motility } \\
\text { B27 - ve control } \\
\text { B27 + ve control }\end{array}$ & & NS & $\begin{array}{l}\text { NS } \\
\text { NS }\end{array}$ & $\begin{array}{l}0.001 \\
0.001\end{array}$ \\
\hline
\end{tabular}




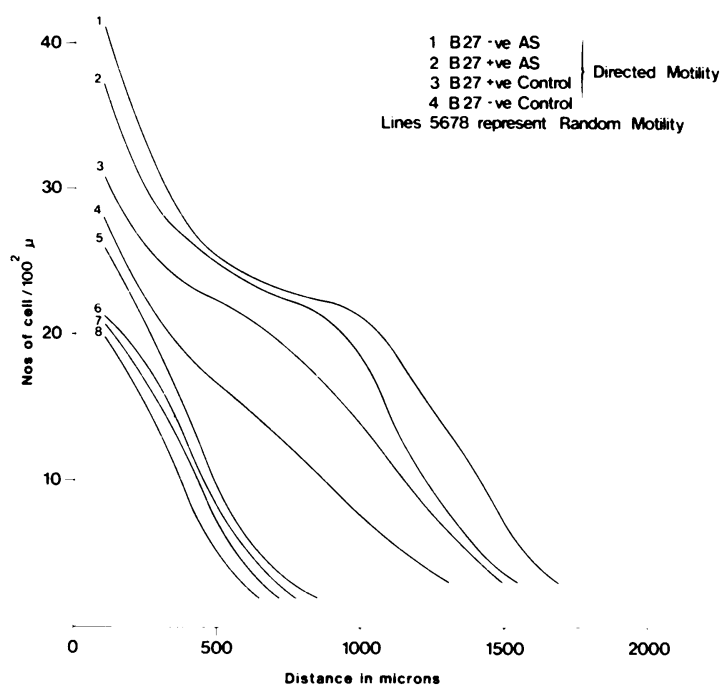

Fig. 2 Polymorphonuclear cell distribution within a 100 $\mu \mathrm{m}$ wide corridor, on the agarose plate, for directed and random motility results.

\section{Discussion}

The interpretation of PMN motility studies is complicated by differences in the techniques employed. In this study, therefore, we have used 2 entirely different systems - migration through a micropore filter and migration under an agar film-and applied 3 different measurements of cell motility: the leading 2-cell front, the total number of cells migrating, and the leucotactic index of Maderazo and Woronick. ${ }^{10}$

The results by these different techniques show a consistent trend for the PMN from patients with AS, whether B27 + ve or B27 - ve, to show increased directed motility compared with B27 - ve controls. In fact the B27 - ve AS were the most motile as judged by all our different indices. Further, cells from B27 + ve controls behave like those from AS patients. It is as if both the disease AS and possession of B27 are associated with increased motility. This effect is, however, apparently not additive in those AS patients who are B27 + ve. The results for random motility vary with the different techniques. Certainly there is no evidence that it is increased in patients with AS or in B27 + ve controls. If anything the trend is in the opposite direction. Phagocytosis and adherence of PMN were studied only in healthy controls. There was no evidence of any difference between those with and those without B27.

Before considering the implications of these results we must ask 2 questions: could the observed changes be due to drug effects, and why have different laboratories produced inconsistent results? Nonsteroidal anti-inflammatory drugs have been shown to influence cell motility, ${ }^{11}$ but the effect was one of inhibition, and it appears unlikely, therefore, that drug therapy could account for the opposite effect observed here in the AS patients. The controls were not taking anti-inflammatory drugs.

In contrast with our findings Mowat ${ }^{12}$ did not detect differences in PMN motility between AS patients and controls. However, his subjects were not tissue typed, and there were important differences in technique. In particular the filters were incubated for 3 hours, whereas we used a 20 -minute incubation. There are technical reasons why this longer incubation period may markedly influence the results. ${ }^{13}$ Clinically, in the control population there was no evidence of a spondarthropathy. However, as we did not $x$-ray our control subjects, we cannot be certain that they did not include some with radiological sacroiliitis. Disease activity did not appear to influence cell motility; however, we felt that most of our patients had inactive disease.

Leirsalo et al. ${ }^{4}$ studied PMN motility in patients with yersinia arthritis and compared these results with those in B27+ve and - ve controls. Their conclusions were that motility was increased in the B27+ve population irrespective of the presence of yersinia arthritis when compared with the B27 - ve diseasefree control group. Motility of PMN from B27 - ve yersinia arthritis patients was similar to that in the B27 - ve controls. However, the former group was tested only after 'complete clinical recovery.' It appears likely therefore either that any alteration in PMN motility had recovered or that yersinia arthritis differs from AS in this regard.

Although the biological significance of this observation is unclear, it is possible that it is a reflection of the same factor(s) which predispose people with B27 to develop ankylosing spondylitis.

Laitinen et al. ${ }^{14}$ discussed the clinical features of 49 B27 + ve and 25 B27 -ve patients with yersinia arthritis and concluded that the severity of the joint symptoms, and complications such as carditis. iritis. and conjunctivitis, were all more marked in the B27 + ve group.

Repo and his colleagues ${ }^{5}$ studied the effect of sera on PMN migration and conclude that $\mathrm{B} 27+\mathrm{ve}$ serat are more chemokinetic than B27 - ve sera. Thes suggest from this and earlier work ${ }^{4}$ that the re are serum associated factors and differences in the responsiveness of $\mathrm{B} 27$ + ve cells to activated sera that might explain the reason why B27 + ve patients develop more inflammatory features of yersinia arthritis. Behçet's syndrome is another condition in which the chemotactic activity of PMNs is 
increased, ${ }^{15}$ and this has been ascribed to the presence of a cytoplasmic activator in the cells.$^{16}$ We have not as yet studied the effect of AS serum on cells. From our results on cell motility there was no obvious difference between the B27 +ve and - ve AS patients. Moreover, AS in B27 -ve patients is thought not to be any less severe than in those with B27. ${ }^{17}$ Our results do not support a role for B27 status in determining disease severity.

There is no reason to suppose that our observations about PMN motility in healthy controls do not reflect-at a biochemical level-an inborn feature of all or most cells in those with B27. The fact that we found a similar functional phenomenon of increased motility among B27 - ve patients with AS implies either that the disease itself may produce this change or that the increased motility reflects an inborn predisposition to AS which is incompletely linked to B27.

We are grateful to Professor Derrick Brewerton of the Westminster Hospital and to Dr Alan Ebringer of the Middlesex Hospital for providing additional patients with ankylosing spondylitis, and also to Professor H. Festenstein of the London Hospital for the tissue typing of patients. The statistics were calculated at the London Hospital computer centre, and we are grateful to Mr Holmes for his help and advice. This work was supported by an Arthritis and Rheumatism Council grant. Dr Colin Pease was in receipt of an Arthritis and Rheumatism Council research fellowship.

\section{References}

1 Nikbin B, Brewerton D A, James D C O, Hobbs $\mathbf{J}$ R Diminished mixed lymphocyte reaction in ankylosing spondylitis, relatives and normal individuals all with HLA B27. Ann Rheum Dis 1976; 35: 37-9.

2 Mawle A C, Hobbs J R, Warren R E, Brewerton D A. Lymphocyte transformation to bacterial antigens in ankylosing spondylitis. Ann Rheum Dis 1979; 38: 197-8.

3 Christiansen F T, Hawkins B R, Dawkins R L. Immune function in ankylosing spondylitis and their relatives. Clin Exp Immunol 1978; 33: 270-5.
4 Leirsalo M, Repo H, Tiilikainen A, Kosunen T, Laitinen O. Chemotaxis in yersinia arthritis. HLA B27 positive neutrophils show high stimulated motility in vitro. Arthritis Rheum 1980; 23: 1036-44.

5 Repo H, Leirsalo M. Tiilikainen A, Laitinen O. Chemotaxis in yersinia arthritis. Arthritis Rheum 1982; 25: 655-61.

6 Dénes L, Géher P, Leckes K, Facus A, Merétey K, Bozsóky S. Adherence and phagocytosis of granulocytes from HLA B27 positive and sero negative arthritic patients and healthy persons. In: Preud'homme J L, Hawken V A L, eds. 4th International Congress of Immunology, Paris, 1980. Published by the organisers of the congress.

7 Bennett P H, Wood P H N. Population studies of the rheumatic diseases. Amsterdam: Excerpta Medica, 1968: 456.

8 Fordham J N, Davies P G, Kirk A, Currey H L F. Polymorphonuclear function in Behçet's syndrome. Ann Rheum Dis 1982; 41: 421-5.

9 Ferrante A, Thong $\mathrm{Y} \mathrm{H}$. A rapid one step procedure for purification of mononuclear and polymorphonuclear leucocytes from human blood using a modification of the hypaque ficoll technique. J Immunol Methods 1978; 24: 389-93.

10 Maderazo E, Woronick C. Micropore filter assay of human granulocyte locomotion problems and solution. Clin Immunol Immunopathol 1978; 11: 196-211.

11 Brown K A, Collins A J. Action of nonsteroidal antiinflammatory drugs on human and rat peripheral leucocyte migration. Ann Rheum Dis 1977; 36: 239-43.

12 Mowat A G. Neutrophil chemotaxis in ankylosing spondylitis. Reiter's disease and polymyalgia rheumatica. Ann Rheum Dis 1978; 37: 9-11.

13 Howe G B, Swettenham K V, Currey H L F. Polymorphonuclear motility: measurement by computer linked image analysis. Blood 1980; 56: 696-700.

14 Laitinen O, Leirsalo M, Skylv G. Relation between HLA B27 and clinical features in patients with yersinia arthritis. Arthritis Rheum 1977; 20: 1121-4.

15 Mizushima Y, Matsumura N, Mori M. Chemotaxis of leucocytes and colchicine treatment in Behçet's disease. $J$ Rheumatol 1979; 6: 108-10.

16 Takeuchi A, Kobayashi K, Mori M, Mizushima Y. The mechanism of hyperchemotaxis in Behçet's disease. $J$ Rheumatol 1981; 8: 40-4.

17 Khan M A, Kushner I, Braun W E. Comparison of clinical features in HLA B27 positive and negative patients with ankylosing spondylitis. Arthritis Rheum 1977; 20: 909-12. 